Serebrennikov Viktor Sergeevich, Ph. D., associate Professor Federal State Budget Educational Institution of Higher Education "The Siberian State Automobile and Highway University" Omsk, Russia, e-mail: vic1983@mail.ru OCID ID: 0000-0002-3795-0953

\title{
IMPROVING THE SYSTEM OF SUPPLY OF FUEL AND LUBRICANTS FLEET IN COLD CLIMATES
}

\begin{abstract}
The article considers the issue of improving the system of supply of fuel and lubricants of transport and technological machines in a cold climate. The use of modern technologies allows for the optimal storage option in the form of a flexible tank. Various models of inventory management, which allow to reduce the financial costs of the enterprise for the replenishment and storage of fuels and lubricants, are analyzed.
\end{abstract}

Keywords: material and technical supply, construction machinery, inventory management, fuel and lubricants, transport and technological machines, tanks

Серебренников Виктор Сергеевич, к.т.н., доцент Федеральное государственное бюджетное образовательное учреждение высшего образования «Сибирский государственный автомобильно-дорожный университет г. Омск, Россия, e-mail: vic1983@mail.ru OCID ID: 0000-0002-3795-0953

\section{СОВЕРШЕНСТВОВАНИЕ СИСТЕМЫ СНАБЖЕНИЯ ГОРЮЧЕ- СМАЗОЧНЫМИ МАТЕРИАЛАМИ ПАРКА МАШИН В УСЛОВИЯХ ХОЛОДНОГО КЛИМАТА}

\begin{abstract}
Аннотация. В статье рассмотрен вопрос совершенствования системь снабжения горюче-смазочными материалами транспортно-технологических машин в условиях холодного климата. Использование современных технологий позволяет реализовать оптимальный вариант хранения в виде гибкого резервуара. Проанализированы различные модели управления запасами, которые позволяют снизить финансовые затраты предприятия на пополнение и хранение горюче-смазочных материалов.
\end{abstract}

Ключевые слова: материально-техническое снабжение, строительные машины, управление запасами, горюче-смазочные материаль, транспортно-технологические машинь, резервуары

The main oil and gas fields in Russia, the popularity of which is growing rapidly, are the territories of the North and the Arctic. Due to the large amount of work in these areas, transport and technological machines need regular and uninterrupted supply of fuel. However, the question immediately arises where and how to store petroleum products in such a harsh climate, where a constant supply of fuel is impossible, while taking into account environmental, industrial and economic factors. For such purposes, specially designed soft tanks are used to store liquid fuel at extreme temperatures from -55 to +80 degrees [1].

Soft tanks are designed for long-term storage of fuel and lubricants. They are indispensable in cases where it is necessary to deliver fuel to a remote field or in a remote place, when the weight and mobility of tanks play a big role, as well as when there is no time or

Technical science - system of supply of fuel
Materials of International Practical Internet Conference "Challenges of Science" 
opportunity to make the Foundation for metal tanks. Flexible tanks have a number of advantages, such as: minimum transport costs, simple and quick preparation of the tank for the discharge of oil products, no need for the organization of sites and special preparatory work, multiple use and virtually unlimited service life, small size and transport weight, corrosion resistance, etc. [2].

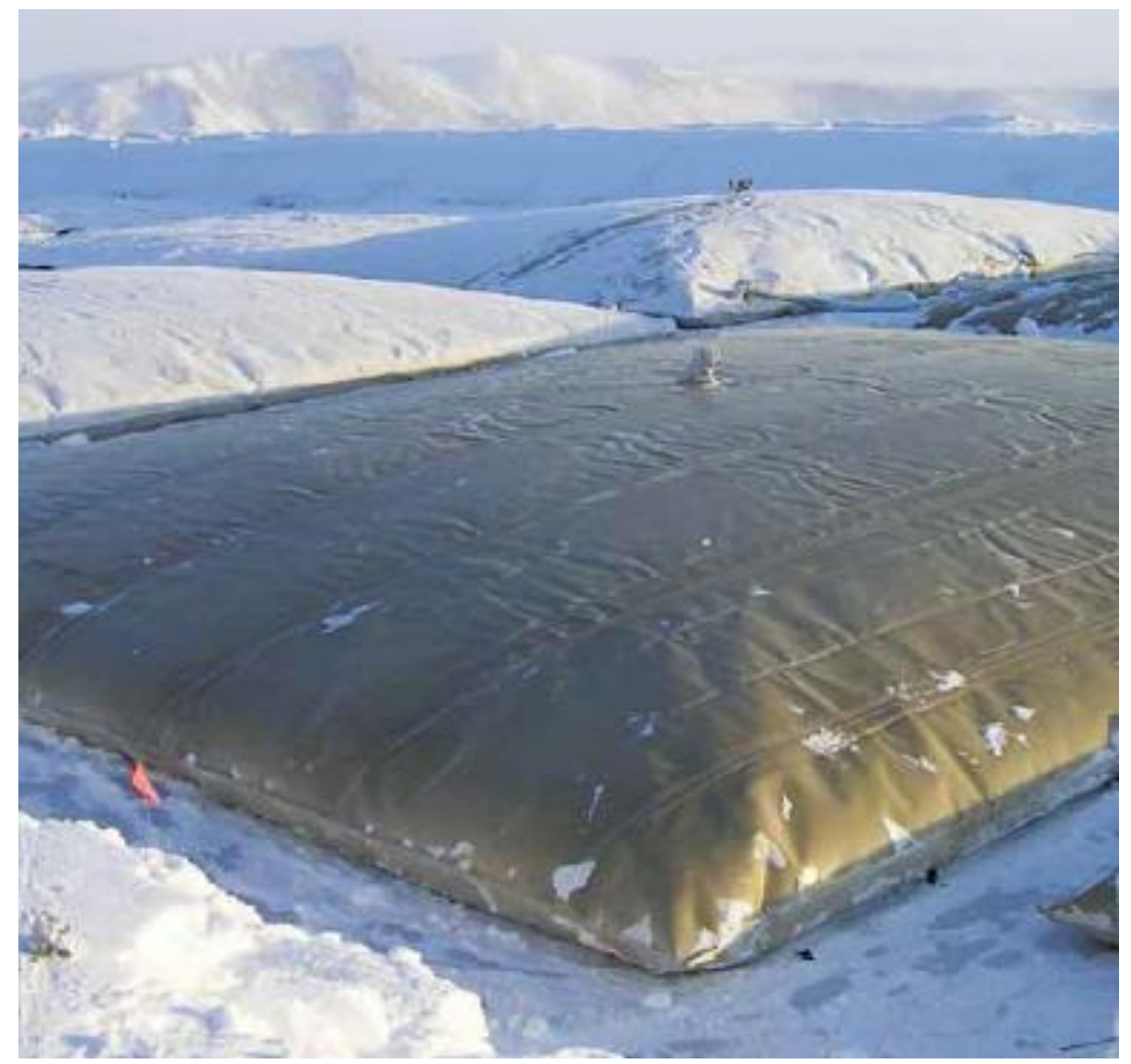

Figure 1 - Soft fuel storage tank

But as experience shows, for the effective operation of the Park of oil and gas and construction equipment requires competent organization and management of fuel supply. For such purposes, there is a service of material and technical support of the operational enterprise, which considers various models of inventory management of fuels and lubricants, to minimize the total cost of replenishment and storage of material and technical resources.

The following inventory management models exist: a model with a fixed order size, a model with fixed intervals between orders, a model with a fixed order size and periodic inventory control, and others [3].

Model with fixed order size (fig. 2) is a permanent control of the level of reserves. A replenishment order has a fixed quantity and is generated when the inventory level drops to the"order point". The level of the "order point" includes the estimated volume of consumption of the considered material and technical resource during the implementation of the order and the safety stock necessary to ensure the required level of reliability of supply of this material and technical resource with possible fluctuations in the level of demand and the time of implementation of the order [4]. 


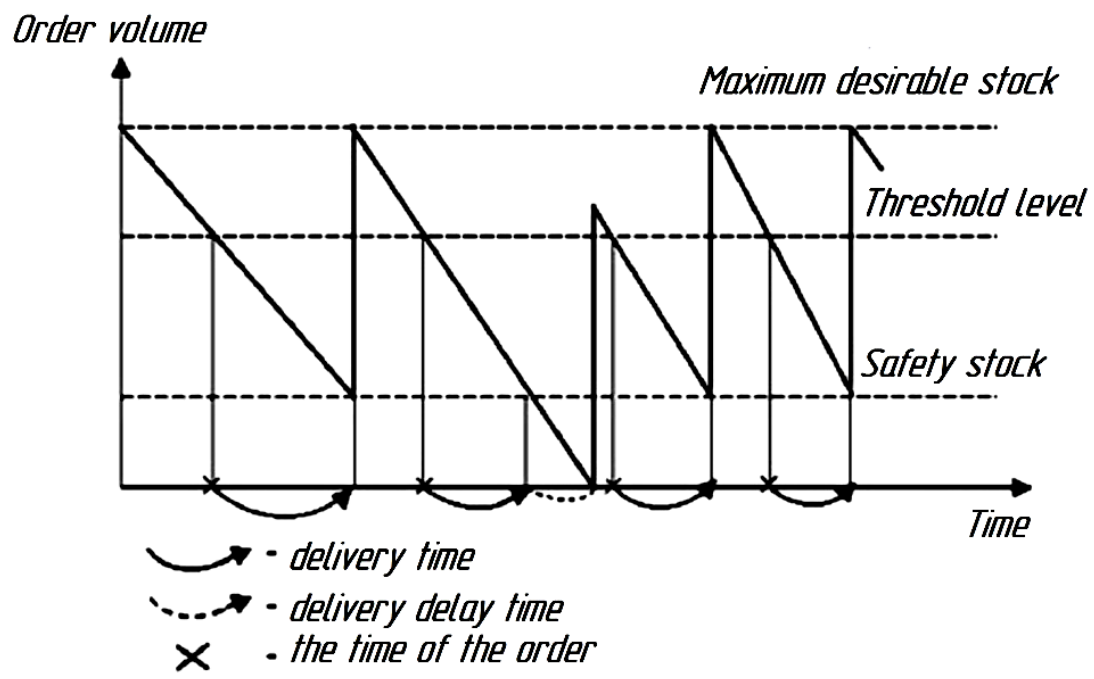

Figure 2 - Inventory management system with fixed order size

The batch size of the order should minimize the total cost of replenishment and storage of the stock under the specified delivery conditions. The optimal order model works well in conditions of constant or slightly changing demand, as well as constant or slightly changing replenishment time.

Model with a fixed time interval between orders (fig. 3) provides for periodic monitoring and replenishment of stocks after a fixed period of time. Replenishment of the stock is made to a fixed (maximum) level, ensuring the satisfaction of the needs for this material and technical resource during the entire interval between orders (up to the arrival of the next batch).

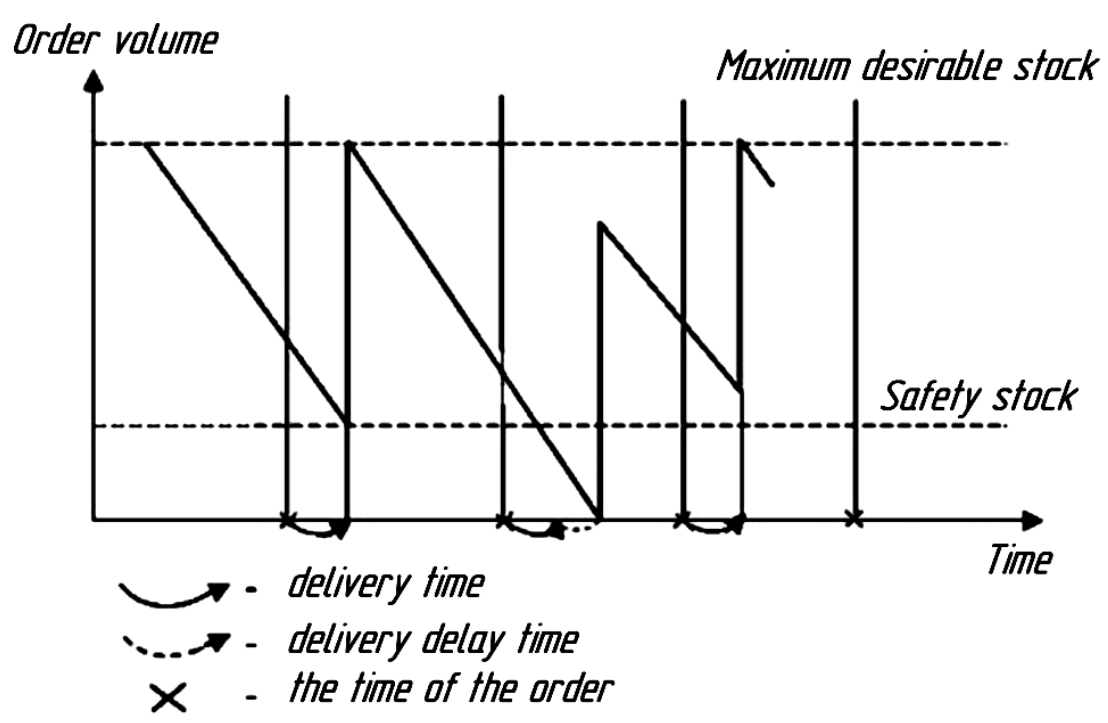

Figure 3 - Inventory management system with a fixed time interval between orders

The interval between orders or selected by minimizing the total costs of replenishment and storing of reserves under specified conditions of supply (i.e. given the minimum party of the order, periodicity of deliveries, system of discounts, etc.), or dictated by the conditions of supply (which may be associated with, for example, features of the production or transport of supplied resources). 
A model with a fixed interval between orders, as well as a model with a fixed order size, works well in conditions of constant or slightly changing demand, as well as constant or slightly changing replenishment time. An important advantage of both models considered is that they allow to organize the supply process on a "no-demand" basis, when consumers simply receive the required material and technical resources in the right quantities and at the right time, and the suppliers record the actual consumption and make purchases, focusing on the current levels of inventory balances.

Model with fixed order size and periodic inventory control (fig. 4), assuming replenishment of the stock of material and technical resources in the fixed volume exceeding (usually multiples) its average expense for the time between checks of level of stocks [5].

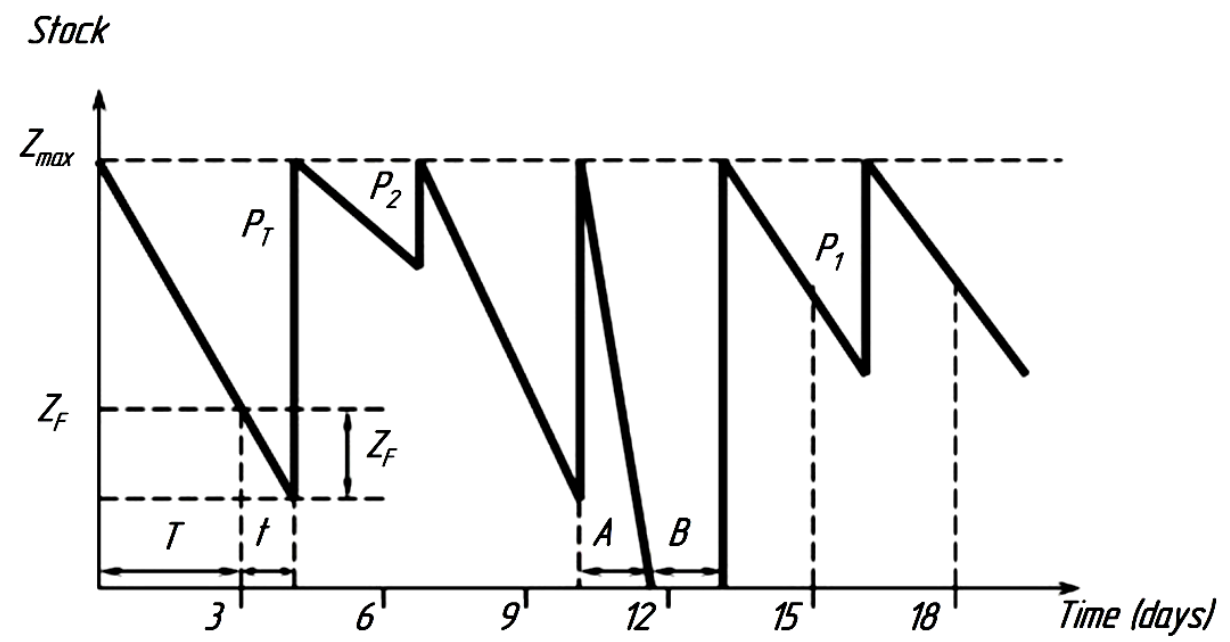

Figure 4 - Inventory management System with a fixed order size and periodic inventory control: $T$ - the time interval through which the order is repeated; $t$ - the time to place and execute the order; $P_{1}, P_{2}$, ... $P_{i}$ - the value of the individual $i$-order; $Z_{\max }$ - the maximum order; $Z_{F}$ - the actual stock; $Z_{T}$ - the stock consumed during the time trequired for placing and executing the order; $A$ - the time period with intensive stock; $B$ - the time period with zero stock

Comparing the results of calculations of different models of fuel management, it is possible to choose the most optimal, allowing to provide high-quality and uninterrupted supply of operational enterprises. The variant of application of soft tanks proposed by the author promotes increase of efficiency of storage and transportation of fuels and lubricants in the conditions of the Arctic zone of Russia.

\section{Literaturquelle}

1. Kovaleva A. From ecology to economy. Sfera Neftegaz, 2011, 1, $94-96$.

2. Tanks for oil products [Electronic resource]. - Access mode: https://neftetank.ru/products/rezervuary-dlya-transformatornogo-masla. - (Date of application: 23.03.2018).

3. Sergeev, V. I. logistics of supply: textbook for bachelor's and master's degrees / V. I. Sergeev, I. p. Elyashevich ; under the General ed. - 3rd ed., TRANS. and extra - M.: Urait, 2018. - 384 p.

4. Methods of selection of inventory management model: Portal "production Management". [Electronic resource.] 2010. Date updated: 25.11.2014. URL: http://www.uppro.ru/library/logistics/supply_management/upravlenice-zapasami.html (date accessed: 23.03.2018).

5. Inventory control systems [Electronic resource]. - Access mode: http://learnlogistic.ru/sistemykontrolya-za-sostoyaniem-zapasov. - (Date of application: 23.03.2018). 